\title{
Block and boulder transport in Eastern Samar (Philippines) during Supertyphoon Haiyan
}

\author{
S. M. May ${ }^{1}$, M. Engel ${ }^{1}$, D. Brill ${ }^{1}$, C. Cuadra ${ }^{2}$, A. M. F. Lagmay ${ }^{2,3}$, J. Santiago ${ }^{2}$, J. K. Suarez ${ }^{2}$, M. Reyes ${ }^{4}$, \\ and H. Brückner ${ }^{1}$ \\ ${ }^{1}$ Institute of Geography, Universität zu Köln, Albertus-Magnus-Platz, 50923 Cologne, Germany \\ ${ }^{2}$ Project NOAH (Nationwide Operational Assessment of Hazards), Department of Science \\ and Technology, Quezon City, Philippines \\ ${ }^{3}$ National Institute of Geological Sciences, University of the Philippines, Diliman, \\ Quezon City 1101, Philippines \\ ${ }^{4}$ Marine Science Institute, University of the Philippines, Velasquez St., Diliman, Quezon City 1101, Philippines \\ Correspondence to: S. M. May (mays@uni-koeln.de)
}

Received: 30 July 2015 - Published in Earth Surf. Dynam. Discuss.: 25 August 2015

Revised: 16 November 2015 - Accepted: 24 November 2015 - Published: 1 December 2015

\begin{abstract}
Fields of dislodged boulders and blocks record catastrophic coastal flooding during strong storms or tsunamis and play a pivotal role in coastal hazard assessment. Along the rocky carbonate coast of Eastern Samar (Philippines) we documented longshore transport of a block of $180 \mathrm{t}$ and boulders (up to $23.5 \mathrm{t}$ ) shifted upslope to elevations of up to $10 \mathrm{~m}$ above mean lower low water level during Supertyphoon Haiyan on 8 November 2013. Initiation-of-motion approaches indicate that boulder dislocation occurred with flow velocities of 8.9$9.6 \mathrm{~m} \mathrm{~s}^{-1}$, which significantly exceeds depth-averaged flow velocities of a local coupled hydrodynamic and wave model (Delft3D) of the typhoon with a maximum $<1.5 \mathrm{~m} \mathrm{~s}^{-1}$. These results, in combination with recently published phase-resolving wave models, support the hypothesis that infragravity waves induced by the typhoon were responsible for the remarkable flooding pattern in Eastern Samar, which are not resolved in phase-averaged storm surge models. Our findings show that tsunamis and hydrodynamic conditions induced by tropical cyclones may shift boulders of similar size and, therefore, demand a careful re-evaluation of storm-related transport where it, based on the boulder's sheer size, has previously been ascribed to tsunamis.
\end{abstract}

\section{Introduction}

Fields of dislocated boulders and blocks are among the most impressive sedimentary evidence of catastrophic coastal flooding (Williams and Hall, 2004; Scicchitano et al., 2007; Goto et al., 2010, 2011; Etienne et al., 2011; Nandasena et al., 2011; Richmond et al., 2011; Engel and May, 2012; Terry et al., 2013) and are widely used to infer the most extreme magnitudes of marine flooding events (tsunamis, storm surges) over large timescales (Etienne et al., 2011; Engel and May, 2012; Terry et al., 2013). Criteria to distinguish between tsunamis and storms include exponential landward fining of boulder fields or the generation of ridges due to strong storms, as well as more random scattering of boul- ders through tsunamis (Goto et al., 2010; Richmond et al., 2011). For some boulder deposits, storm transport was ruled out based on their large size, elevation and distance from the coast, and local extreme storm wave conditions (Scicchitano et al., 2007; Engel and May, 2012), while the long wave period of tsunamis has been associated with a higher transport competence (Lorang, 2011). However, the topic is still a matter of considerable debate (Goto et al., 2010; Lorang, 2011); until recently, only few studies provided unambiguous evidence for the transport of very large clasts during storms (Goto et al., 2011), e.g. based on direct observations, reliable historical documentation, or satellite data (Table 1). However, dimensions and transport distances of these clasts are 
Table 1. Boulder axes, volume, and weight of very large storm-transported clasts from the literature documented by eyewitnesses or remote sensing. Uncorrected and tentatively corrected volumes $\left(V_{\mathrm{abc}}, V_{\mathrm{corr}}\right)$ and weights $\left(W_{\mathrm{abc}}, W_{\mathrm{corr}}\right)$ are given using a correction factor of 0.6 ( 0.8 for the rather cubic boulder at Bondi; Boyson, 2012; Google Earth/Digital Globe, 2015). $T_{1}$ : lateral transport; $T_{\mathrm{v}}$ : vertical transport; $\rho_{\mathrm{b}}$ : bulk density. The displacement of the above-indicated clasts occurred due to direct storm wave impact. For the block at Bondi Beach the original source gives a weight of "about $235 \mathrm{t}$ " (Süssmilch, 1912, p. 155), whereas multiplication of axes and local rock density of ca. $2.35 \mathrm{~g} \mathrm{~cm}-3$ (Süssmilch, 1912; Verhoef, 1993) reveals only 211 t. Furthermore, questions about the reliability of the report on the storm wave transport in 1912 have been raised, citing pre-1912 photographs of the boulder in its present position (Cass, 2002; Scheffers et al., 2008).

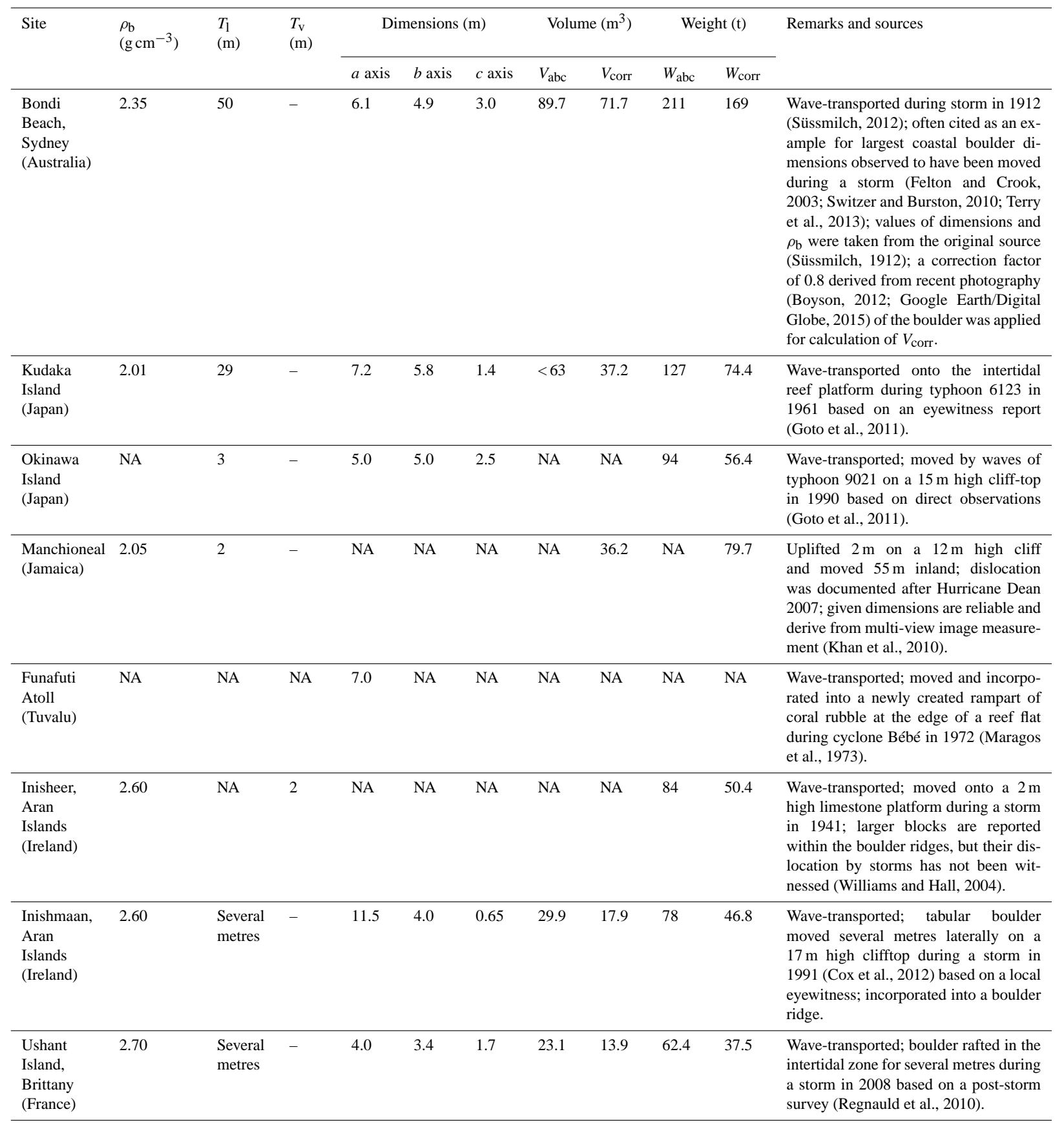

often significantly smaller than those of palaeo-deposits for which the mode of transport is unknown.

We present evidence for onshore block and boulder dislocation at the carbonate coast of Eastern Samar (Philippines;
Fig. 1) during Supertyphoon Haiyan (local name: Yolanda), one of the strongest tropical cyclones (TCs) on record. Using sedimentary parameters of the clasts (spatial distribution, size, orientation, etc.), bi-temporal satellite images, charac- 


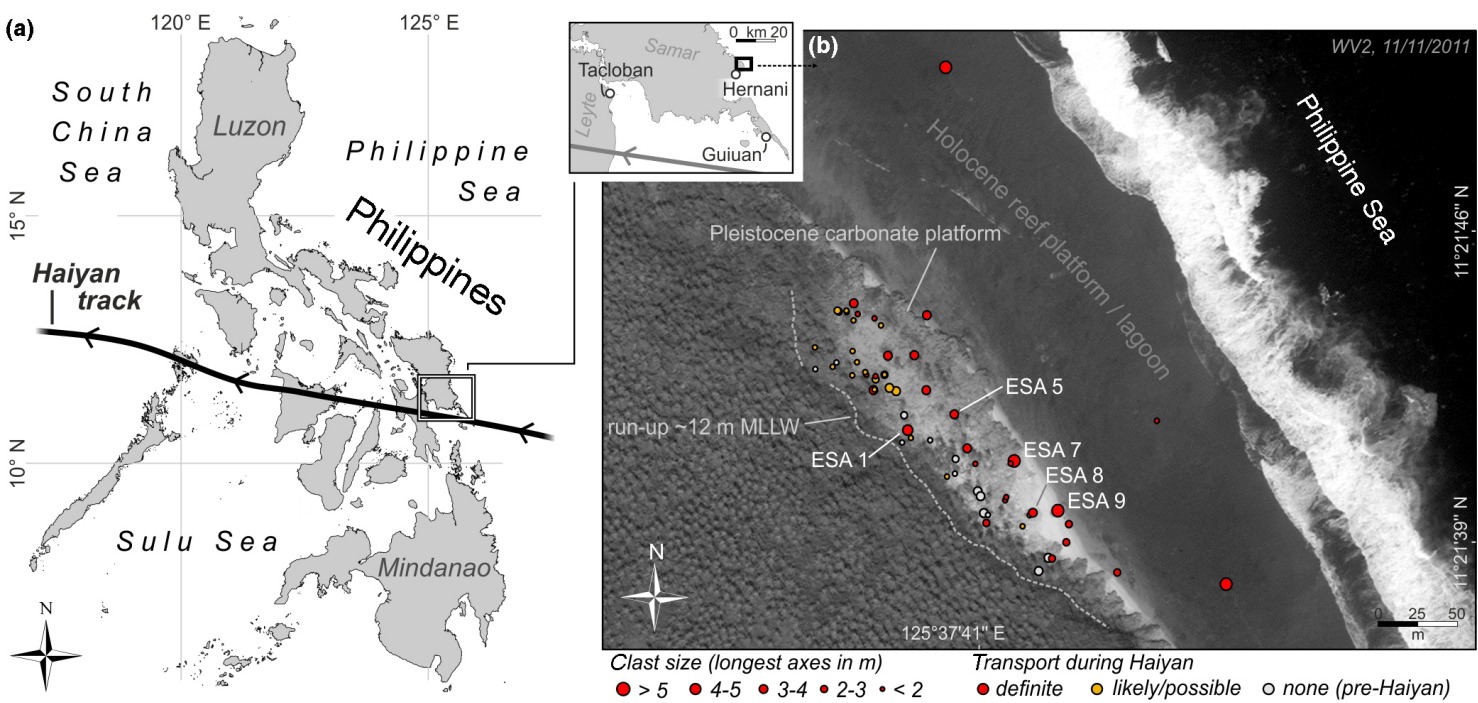

Figure 1. Study area and boulder field at site ESA. (a) Location of study area and Haiyan's track. (b) Setting of the boulder field at site ESA (59 clasts documented). The post-Haiyan image illustrates the extent of destroyed vegetation and deposited sand (light grey, on top of the Pleistocene carbonate platform) (WV2, 11 November 2013). Large clasts were moved on top of the Holocene reef as well as on top of the Pleistocene platform. A number of boulders ( $~ 30$ clasts) were definitely transported, and dislocation of several further boulders is very likely. Further clasts must have been transported during an older palaeo-wave event.

teristics of the storm surge and waves inferred from local numerical models, and inverse modelling of minimum flow velocities required to initiate boulder movement, we provide insights into the hydrodynamic and sedimentary processes during a TC. These insights have important implications for the boulder-related "storm vs. tsunami" debate.

\section{Physical setting}

Situated directly north of Leyte, the island of Samar is part of the Eastern Visayas (Philippines) (Fig. 1a). It faces the Philippine Sea with the Philippine Trench and subduction zone to the east and the Philippine Fault to the west, the latter comprising a $1200 \mathrm{~km}$ long system of strike-slip faults crossing Leyte in a NW-SE direction (Barrier et al., 1991; Ramos and Tsutsumi, 2010). The inner part of Samar consists of Cretaceous to Oligocene igneous rocks, surrounded by mostly carbonate rocks of Mio-Pliocene age showing typical karst morphology (Traveglia et al., 1978).

Along the coast of Eastern Samar, Holocene fringing coral reefs are up to several hundred metres wide (Fig. 1b). Offshore, the bathymetry immediately drops down towards the Philippine Trench. Similar to other coastal areas in the Philippines, elevated reef terraces of last interglacial age (e.g. Omura et al., 2004) are present along the Eastern Samar coast as well, e.g. near the municipality of Hernani, where this study was conducted. Based on our DGPS measurements, the tidal range at site ESA on 17 February 2014 amounted to $1.5 \mathrm{~m}$, which is similar to the tidal range of Laong (N Samar) given in Maeda et al. (2004).

\section{Supertyphoon Haiyan}

\subsection{Course of the event}

Originating from a tropical depression which formed on 3 November 2013 over the northwestern Pacific, Supertyphoon Haiyan turned into a tropical storm on 4 November and gained typhoon status on 5 November. On 6 November Haiyan reached the status of a category 5 cyclone on the Saffir-Simpson hurricane scale and made landfall near Guiuan (Eastern Samar) at 04:40 on 8 November (IRIDeS, 2014; Lagmay et al., 2015). Haiyan crossed the entire archipelago in a westward direction without falling below category 5 on the Saffir-Simpson hurricane scale (Figs. 1a, 2). Further landfalls occurred at 07:00 on northern Leyte (close to Dulag), and later on northern Cebu, Panay, and Palawan. Due to sustained wind speeds of up to $314 \mathrm{~km} \mathrm{~h}^{-1}$ ( $1 \mathrm{~min}$ average based on remote sensing data) and a heavy storm surge leading to rapid, extensive flooding, Haiyan was an extraordinary natural disaster, causing 6300 casualties and affecting more than 16 million people (NDRRMC, 2014a; Lagmay et al., 2015).

\subsection{Coastal flooding and hazard response}

Coastal flooding rapidly reached peak levels that lasted for approximately $2 \mathrm{~h}$. It was locally characterized by multiple pulses of inflowing waves with periods of several seconds (Mas et al., 2015); eyewitnesses on Leyte and Samar reported a threefold withdrawal of the sea followed by distinct flooding pulses, and waves superimposing the storm surge reached up to $4 \mathrm{~m}$ in Tacloban. In Eastern Samar, wave periods of 10 
$20 \mathrm{~s}$ were reported (Mas et al., 2015). High flow velocities of uprushing currents were inferred from a survivor video at Hernani, which approached for more than $1 \mathrm{~min}$ before receding (Gensis, 2013; Bricker and Roeber, 2015; Mas et al., 2015). Post-typhoon interviews with residents suggest that, similar to how TC Nargis had impacted Myanmar's Ayeyarwady Delta in 2008 (Fritz et al., 2009), the coastal population of Leyte and Eastern Samar lacked a proper understanding of the dimensions and devastating effects potentially connected with the term "storm surge". This lack of awareness is typically linked to the low frequency of such highest-magnitude events (Fritz et al., 2009), a relationship best described by inverse power-law functions (Corral et al., 2010). Personal experience and adaptation is commonly restricted to events of much smaller magnitude. This classical relationship emphasizes the pivotal role of geological records of extreme-wave events for coastal hazard assessment as they may provide information on local to regional frequencymagnitude patterns over millennial timescales and can also be implemented in education and raising awareness among residents (Weiss and Bourgeois, 2012).

The exposed coast of Eastern Samar is characterized by a large fetch and a steep offshore bathymetry. Hence, it experienced maximum wind speeds with the highest modelpredicted waves of up to $19 \mathrm{~m}$, but only a limited wind-driven surge during Haiyan (Bricker et al. 2014). Field indicators document inundation levels of up to $6 \mathrm{~m}$ onshore flow depth, nearly $11 \mathrm{~m}$ run-ups above local event tide level, and inundation distances of up to $800 \mathrm{~m}$ depending on onshore topography (Quinto et al., 2014; Tajima et al. 2014; Shimozono et al., 2015).

\subsection{Previous typhoons and storm systems}

Eastern Samar has repeatedly been impacted by severe typhoons in the historical past although they are generally less frequent compared to coastal areas further north. Catastrophic typhoons with tracks similar to the one of Haiyan occurred on 12-13 October 1897 (Soria et al., 2015), on 2425 November 1912 (Philippine Weather Bureau, 1912), and on 4 November 1984 (Typhoon Undang/Agnes, category 4 on SSHS) (JTWC, 1985). However, on historical timescales, Supertyphoon Haiyan is believed to be the strongest typhoon to have hit Eastern Samar (Lapidez et al., 2015).

Pre-Haiyan satellite images available for comparison with images captured after Haiyan date to 4 May 2013. PostHaiyan images were captured 3 days after the typhoon on 11 November 2013, thereby excluding subsequent typhoons such as Basyang (31 January 2014; NDRRMC, 2014b) for coarse-clast transport. Between 4 May and 8 November 2013, three storm systems occurred within an area of ca. $250 \mathrm{~km} \mathrm{~N}, \mathrm{~S}$, and $\mathrm{E}$ of Eastern Samar, according to the typhoon database of the Joint Typhoon Warning Center (JTWC, 2014). The tracks of two of these storm systems crossed an area of $120 \mathrm{~km}$ surrounding the study area,

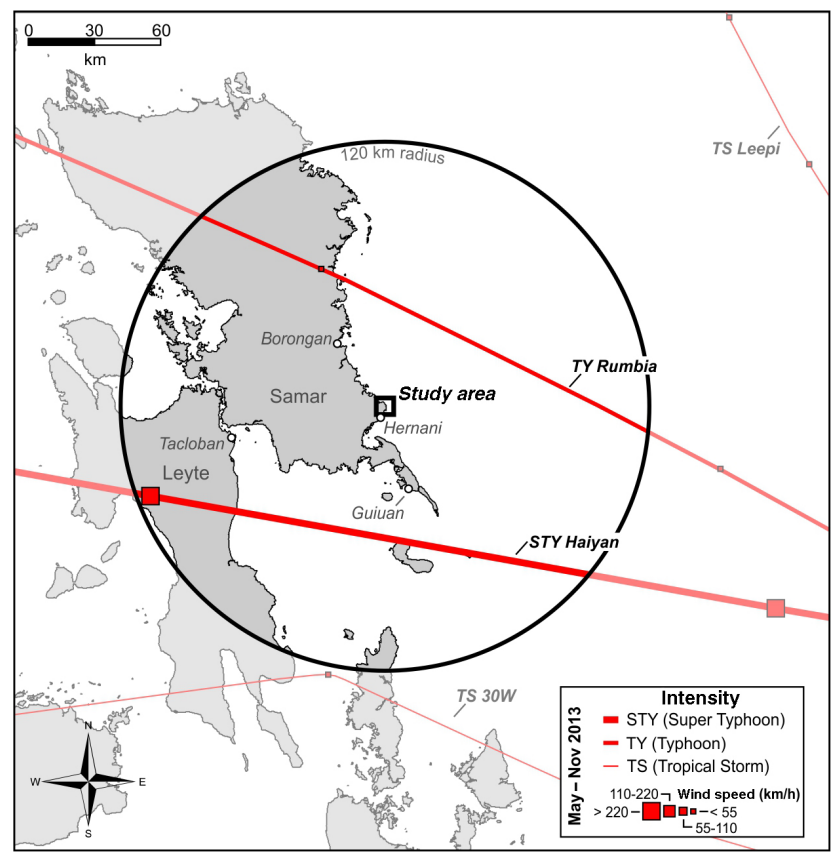

Figure 2. Previous typhoons and tropical storms. Location of study area, track of Supertyphoon Haiyan, and tracks of three further storm systems which occurred within an area of ca. $250 \mathrm{~km} \mathrm{~N}, \mathrm{~S}$, and E of Eastern Samar between 4 May and 11 November 2013 (JTWC, 2014). Tropical storm 30W (3-6 November 2013) and Typhoon Rumbia (27 June-2 July 2013) only reached moderate wind speeds of $\leq 65 \mathrm{~km} \mathrm{~h}^{-1}$ and atmospheric pressures of $>995 \mathrm{hPa}$ when passing the $120 \mathrm{~km}$ radius around the study area.

extending from the northern tip of Mindanao to Northern Samar (Fig. 2). Tropical storm 30W (3-6 November 2013) only reached moderate wind speeds of $\leq 60 \mathrm{~km} \mathrm{~h}^{-1}$ when passing the $120 \mathrm{~km}$ radius, and its atmospheric pressure remained above $1000 \mathrm{hPa}$. Typhoon Rumbia (27 June-2 July 2013) had a northern track and made landfall at the city of Taft some $65 \mathrm{~km}$ north of the study area. However, it had maximum wind speeds of $\leq 64 \mathrm{~km} \mathrm{~h}^{-1}$ and reached a minimum atmospheric pressure of $996 \mathrm{hPa}$ while approaching the coasts of Eastern Samar and Leyte (JTWC, 2014). Based on the low number of storm systems between May and November 2013 and their rather moderate intensity compared to Supertyphoon Haiyan, we ascribe any major block and boulder transport inferred from the satellite images to the latter event.

\section{Methods and data}

\subsection{Interpretation of satellite images}

Panchromatic satellite images of World View 1 (WV1, ID 1020010021141100, 4 May 2013) and WV2 (ID 10300100294524000, 11 November 2013) were used for mapping of the pre- and post-Haiyan position of wavetransported large clasts between Hernani and the study 
site. The original georeferenced images were aligned based on unaltered coastal structures such as cliff edges using ESRI ArcGIS software, resulting in a positional accuracy of $\sim 2$ pixels $(\sim 1.2 \mathrm{~m})$. Satellite image-based mapping was restricted to clasts which were not covered/hidden by the dense vegetation on the pre-Haiyan image.

\subsection{Field and laboratory work}

In the field, the elevation of all dislocated clasts was measured using a Topcon HiPer Pro differential global positioning system (DGPS) with an altimetric accuracy of $\pm 2 \mathrm{~cm}$. Elevations were referenced to mean lower low water level (MLLW). The first field survey was carried out in February 2014, 3 months after the typhoon. A second field survey was conducted between 5 and 20 March 2015. Altogether 59 clasts with longest axes $>1 \mathrm{~m}$ were documented in the field at site ESA (Fig. 1b). The clasts were classified as "transported", "not transported", or "possibly transported" during Haiyan based on vegetation cover, weathering patterns and colour of rock surfaces, the freshness of buried plant debris, and satellite imagery. Five of the dislocated boulders (ESA 1, 5, 7-9) were studied in high detail. The original (pretransport) position of ESA 1 and 5 was identified based on fresh scars in the carbonate platform and the equal pattern of coral branches exposed within the scarp and at the clasts' surface. The carbonate rock at the original position of ESA 7 and 9 appeared less weathered/karstified and has a significantly lighter colour compared to surrounding platform sections, and a $5 \mathrm{~cm}$ high pedestal was documented at the preHaiyan position of ESA 9. The clasts' trajectories and transport distances were identified by tracing impact marks on the carbonate platform using a DGPS. The distribution of fresh percussion marks on the clasts' surface additionally gave evidence for their transport mode.

Two different approaches for calculating the clasts' volumes $(V)$ were applied following the procedure described in a previous study (Engel and May, 2012): (i) $a$ (length), $b$ (width), and $c$ (height) axes of the selected boulders were measured for conventional calculations of $V_{\mathrm{abc}}=a \cdot b \cdot c$ using a measuring tape, and (ii) upper and lower vertices and edges were measured using a DGPS in order to calculate the $V$ with high accuracy. The DGPS-measured point cloud was imported into a GIS (ESRI ArcGIS) and translated into 3-D surfaces by computing triangulated areas between the GPS points. The boulder volume ( $V_{\text {DGPS }}$ ) was then calculated by subtraction of the volume between the boulder's lower surface and the ground surface from the volume between the boulder's upper surface and the ground surface. Discrepancies between the two methods are shown in column $V_{\text {DGPS }} / V_{\text {abc }}$ and represent the correction factor for $V_{\mathrm{abc}}$ values. $V_{\text {DGPS }}$ and other emerging approaches such as terrestrial laser scanning (Hoffmann et al., 2013; Hoffmeister et al., 2014) or multi-view image measurement techniques (Khan et al., 2010; Terry et al., 2013; Gienko and Terry, 2014) are as- sumed to provide the best approximates of the real volume of the clasts. The clasts' bulk density $\left(\rho_{\mathrm{b}}\right)$ was calculated from five samples representative of the lithological composition of ESA 7 using the Archimedean principle (buoyancy in sea water) (Hughes, 1987).

Based on this and a previous study (Engel and May, 2012), best estimates of volume and weight of limestone boulders along tropical coasts are $\sim 60 \%$ of $V_{\mathrm{abc}}$ on average. In addition to the dimensions indicated by the authors, we therefore give corrected volumes ( $\left.V_{\text {corr }}\right)$ and weights $\left(W_{\text {corr }}\right)$ for the largest clasts in the literature for which transport during storms was directly observed (Table 1).

\subsection{Modelling}

By using Delft3D and Delft Dashboard software, a highresolution storm surge model for the boulder site was created and nested into a coarser one, which provides the initial conditions at the open boundaries of the high-resolution model. While the built-in GEBCO (bathymetry) and SRTM (topography) data from Delft Dashboard was used for the coarse model (1 km spatial resolution), IFSAR data (topography) as well as a combination of nautical chart (near-shore bathymetry) and GEBCO (offshore bathymetry) data were used in the nested model. The different data sets were interpolated to the computational grid, resulting in a spatial resolution of $50 \mathrm{~m}$. Further steps in model creation and details on boundary conditions can be found in Cuadra et al. (2014).

Wind forcing in Delft3D was based on a wind enhancement scheme (WES) following Holland's model to generate the tropical cyclone wind field (Holland, 1980). A spiderweb file was generated using the JTWC best track data of Typhoon Haiyan, which includes data about typhoon track, maximum sustained wind speed, and pressure field.

Tides may either reduce or add to the storm surge in the area. For relatively small coastal models such as the nested one presented here, the treatment of tidal forcing along the open boundaries is sufficient in generating the appropriate tidal motion. Tidal forcing in Delft3D was based on the TPXO 7.2 Global Inverse Tide Model to acquire the phases and amplitudes for cells in the model.

In order to derive estimates of minimum flow velocities required to move the dislocated boulders, we applied the equations (initiation-of-motion criteria) of Nandasena et al. (2011). Equations differ based on transport modes. Values for input parameters include boulder axes (derived from field measurements), inclination of original boulder position $(\theta)$ (inferred from DGPS transects), density of sea water $\left(\rho_{\mathrm{w}}\right)$ and the boulder $\left(\rho_{\mathrm{S}}\right)$, boulder-specific coefficients of drag $\left(C_{\mathrm{d}}\right)$, lift forces $\left(C_{1}\right)$, and static bottom friction $(\mu)$. 


\section{Results}

\subsection{Block and boulder transport based on pre- and post-typhoon satellite images}

The comparison of pre- and post-Haiyan satellite images (WV1 and 2) illustrates changes in the position of large interto supratidal clasts at our study site (Fig. 3) and at several further sections of the adjacent coastline (Fig. 4). At site ESA, the largest transported clasts are found in the intertidal zone along the landward margin of the $150 \mathrm{~m}$ wide Holocene lagoon (Figs. 1b, 3a, b). ESA 9 was shifted shore-parallel by $\sim 40 \mathrm{~m}$ along the upper intertidal to lower supratidal of the reef platform. ESA 7 was moved on the lower supratidal platform by $\sim 30 \mathrm{~m}$. Further north, on top of the gently inclined Pleistocene carbonate platform, vegetation (mostly coconut trees) is almost entirely removed in the post-Haiyan image (Figs. 1b, 3b). Large clasts can be spotted on top of the platform at various locations, although in most cases their preHaiyan position remains unknown due to the dense vegetation cover in May 2013. A fresh scarp along the cliff edge at the transition from the carbonate platform to the Holocene lagoon was detected on the post-Haiyan satellite image. Dislocation of further clasts is inferred for the central part of the lagoon, on top of the Holocene reef platform (Fig. 1b).

To the north and south of site ESA, several further clasts were shifted according to the pre- and post-Haiyan satellite images (Fig. 4a-d). Dislocation of large block-sized clasts was spotted some $500 \mathrm{~m}$ north of ESA, where two triangleshaped blocks (with longest axis $>4$ and $>5 \mathrm{~m}$, respectively) were shifted on top of the Holocene reef platform; a distance of $>240 \mathrm{~m}$ is inferred for the smaller one (Fig. 4b). In the omega-shaped bay south of ESA (Pook Cove), just north of Tugnug Point, and in Nagaha Bay, numerous large clasts of pre-existing boulder fields changed position as well (Fig. 4c, d).

\subsection{Field evidence - block and boulder fields in Eastern Samar}

Out of the 59 clasts (longest axes $>1 \mathrm{~m}$ ) documented at site ESA (Fig. 1b), 30 clasts showed clear signs of recent transport, and 13 clasts must have been transported by a previous event based on their mature vegetation cover. For 16 clasts, dislocation during Haiyan remains ambiguous.

At ESA, the largest clast found to be dislocated amounts to $\sim 180 \mathrm{t}$ (ESA 9: $\sim 75 \mathrm{~m}^{3} ; 9.0 \times 4.5 \times 3.5 \mathrm{~m}^{3}$; Fig. 5a, b). Its main axis was slightly turned during transport and is now perpendicular to the shore. The pre-Haiyan location of ESA 9 shows a $\sim 5 \mathrm{~cm}$ high pedestal which had formed below ESA 9 prior to dislocation in the intertidal zone of the reef platform (Fig. 5b). Its source is the receding cliff of the Pleistocene reef terrace. Another large boulder (ESA 7: $\sim 30 \mathrm{~m}^{3}$; $5.3 \times 3.0 \times 2.9 \mathrm{~m}^{3} ; \sim 70 \mathrm{t}$; Fig. $5 \mathrm{c}$ ) was found some $40 \mathrm{~m}$ northwest of ESA 9. Evidence for overturning and rolling

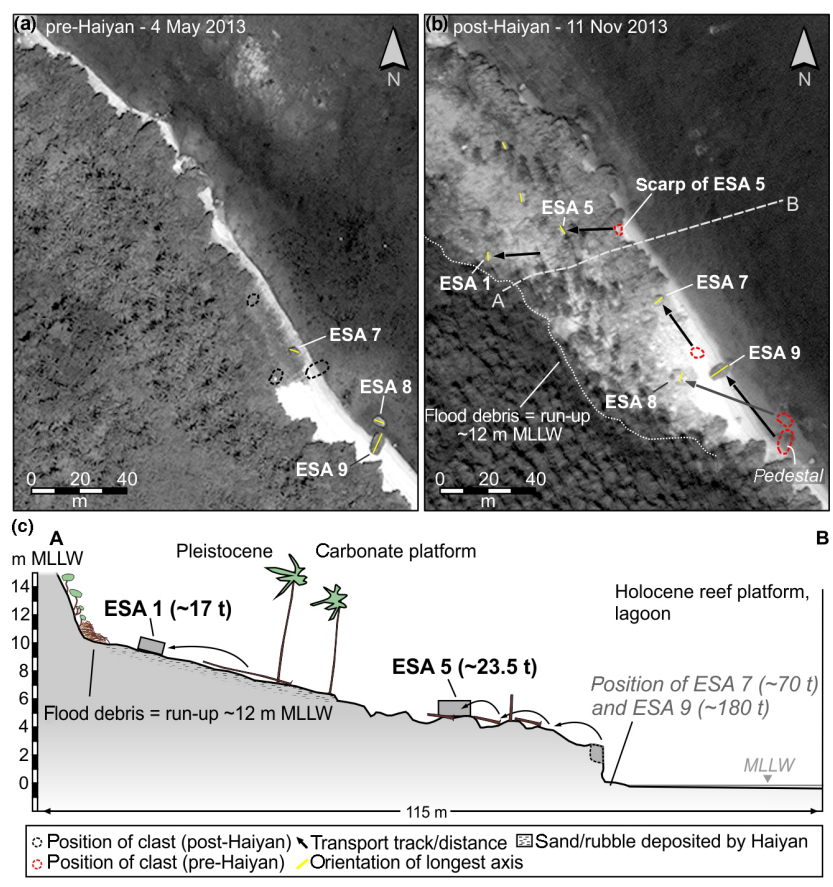

Figure 3. Large clasts transported by Haiyan at site ESA. (a, b) Pre(WV1, 4 May 2013) and post-Haiyan images (WV2, 11 November 2013) illustrating run-up extent; position of clasts ESA 1, 5, 7, 8, and 9; and trajectories. Transport direction of largest clasts ESA 7 and 9 is SE-NW, documenting a NW-directed surge. ESA 9 was moved by $\sim 40 \mathrm{~m}$. (c) Transect A-B. Flood debris at $12 \mathrm{~m}$ MLLW indicates maximum run-up. ESA 5: quarried from cliff edge.

of ESA 7 was found in the form of downward-facing and still-living grass patches, impact marks on the supratidal platform along its track, and fresh wood jammed under the rock (Fig. 6). In contrast, grass patches on top, a lack of impact marks at the surface, and a notch opening towards the base were documented for block ESA 9 and indicate sliding transport and no overturning.

Some $50 \mathrm{~m}$ to the north, numerous slab-shaped boulders were dislocated on top of the gently inclined Pleistocene carbonate platform. A boulder of $\sim 23.5 \mathrm{t}$ (ESA 5: $\sim 10 \mathrm{~m}^{3}$; $4.0 \times 2.8 \times 1.7 \mathrm{~m}^{3}$; Fig. $6 \mathrm{a}$, b) was quarried at $2 \mathrm{~m}$ MLLW from the cliff edge of the carbonate platform, leaving a fresh scarp, which was detected on the post-Haiyan satellite image as well (see also Sect. 5.1). It was transported vertically to $6 \mathrm{~m}$ MLLW by rolling or even saltation. Boulders of up to $\sim 17$ t (e.g. ESA 1; Fig. 5d) were moved upwards from 6.5 to $10 \mathrm{~m}$ MLLW, $2 \mathrm{~m}$ below the highest run-up marks (Fig. 1c). Downward-facing rock pools and grass patches, still-living barnacles, roots and soil staining on the exposed former bottom side, snapped palm trees, and fresh wood jammed under the rocks were found for the clasts on top of the Pleistocene carbonate platform as well (Fig. 6). The pre-Haiyan vegetation was almost entirely devastated, and flood debris displays the limit of highest run-up at $12 \mathrm{~m}$ MLLW. The plat- 


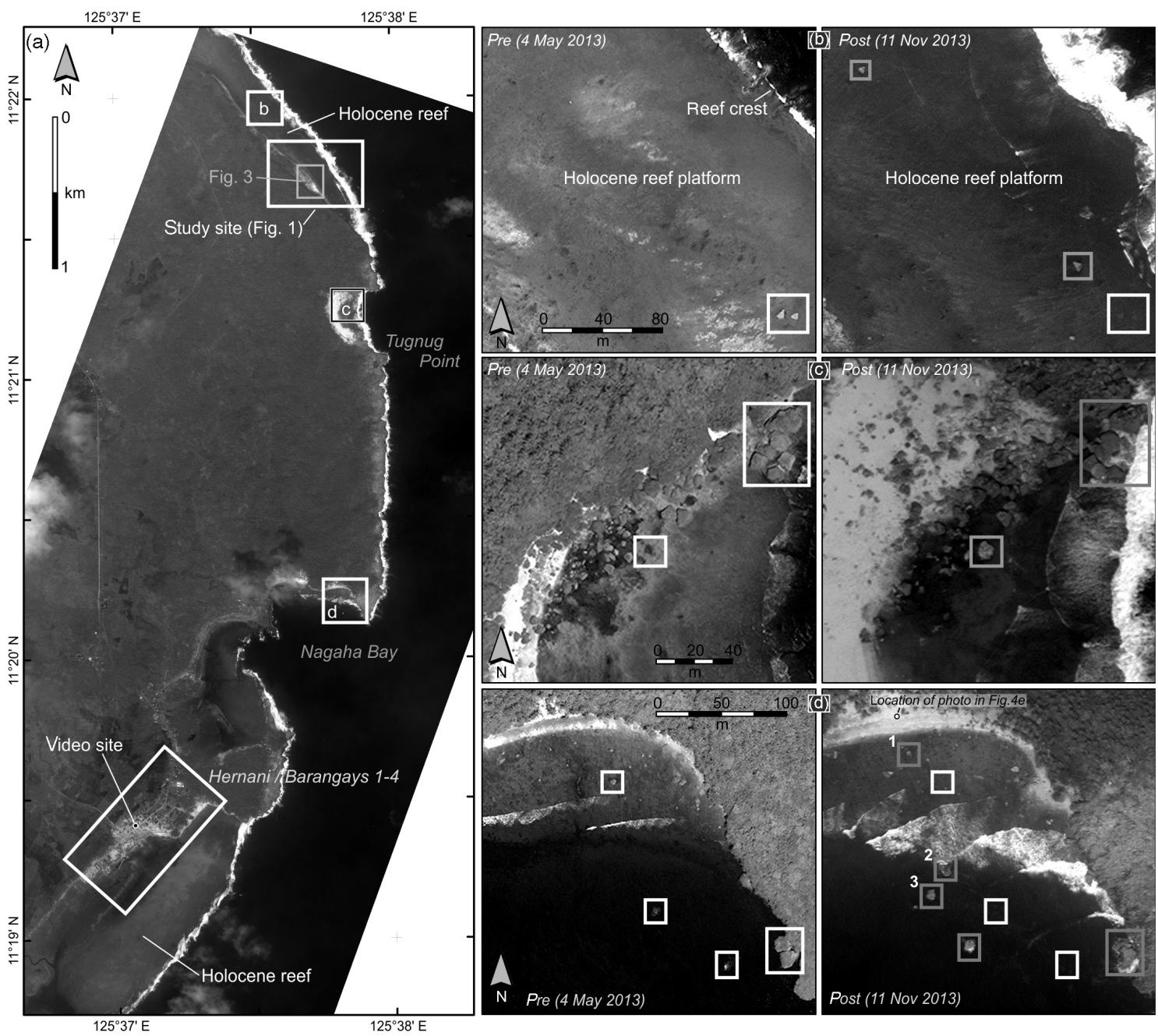

Figure 4. Further evidence of block and boulder transport during Haiyan. (a) Location of study site ESA (see also Figs. 1 and 3), the city of Hernani, including the location of the eyewitness footage (Gensis, 2013), and further sites (b-d) with evidence for Haiyan-induced block and boulder transport. (b) Two triangle-shaped blocks (with axis $>4$ and $>5 \mathrm{~m}$ ) were shifted on top of the Holocene reef platform, some $500 \mathrm{~m}$ north of site ESA; a distance of $>240 \mathrm{~m}$ is inferred for the smaller one. (c, d) South of ESA, numerous large clasts of pre-existing boulder fields changed position. Note dislocation (post-Haiyan imbrication) of large blocks (longest axis $>10 \mathrm{~m}$ ) directly west of the headland and of intertidal clasts to the west; clasts marked by 1-3 are shown in Fig. 5e (d). White boxes mark pre-Haiyan positions and grey boxes the post-Haiyan positions of clasts, or areas showing apparent movements of large clasts.

form is covered by a thick sheet of whitish reef-borne sand and gravel overlying a brownish topsoil horizon developed in an older carbonate sand deposit.

\subsection{Calculation of flow velocities for block and boulder transport}

Blocks and boulders may be moved by fluid forces in the form of sliding, rolling, or saltation (e.g. Nandasena et al. 2011), depending on flow velocity, bottom friction, and the clasts' shape and weight. Based on the pioneering contributions of Nott (1997, 2003), Nandasena et al. (2011) presented improved hydrodynamic equations for calculating estimates of minimum flow velocities $(u)$ necessary for the initiation of coastal block and boulder motion by tsunamis and storms. The equation for the initial transport mode "sliding" of submerged or subaerial (e.g. ESA 9) clasts reads

$u^{2} \geq \frac{2 \cdot\left(\frac{\rho_{\mathrm{s}}}{\rho_{\mathrm{w}}}-1\right) \cdot g \cdot c \cdot\left(\mu_{\mathrm{s}} \cdot \cos \theta+\sin \theta\right)}{C_{\mathrm{d}} \cdot \frac{c}{b}+\mu_{\mathrm{s}} \cdot C_{\mathrm{l}}}$,

where $\rho_{\mathrm{s}}$ is density of the boulder, $2.4 \mathrm{~g} \mathrm{~cm}^{-3} ; \rho_{\mathrm{w}}$ is density of sea water, $1.02 \mathrm{~g} \mathrm{~cm}^{-3} ; g$ is gravitational acceleration, $9.81 \mathrm{~m} \mathrm{~s}^{-2} ; c$ is boulder's height (in all cases the boulder's shortest axis); $b$ is boulder's width (in all cases the boulder's second longest axis); and $\theta$ is angle of the bed slope. We applied boulder-specific values for $C_{\mathrm{d}}$, coefficient of drag (Table 2), by calculating boulder-specific shape factors (Corey, 


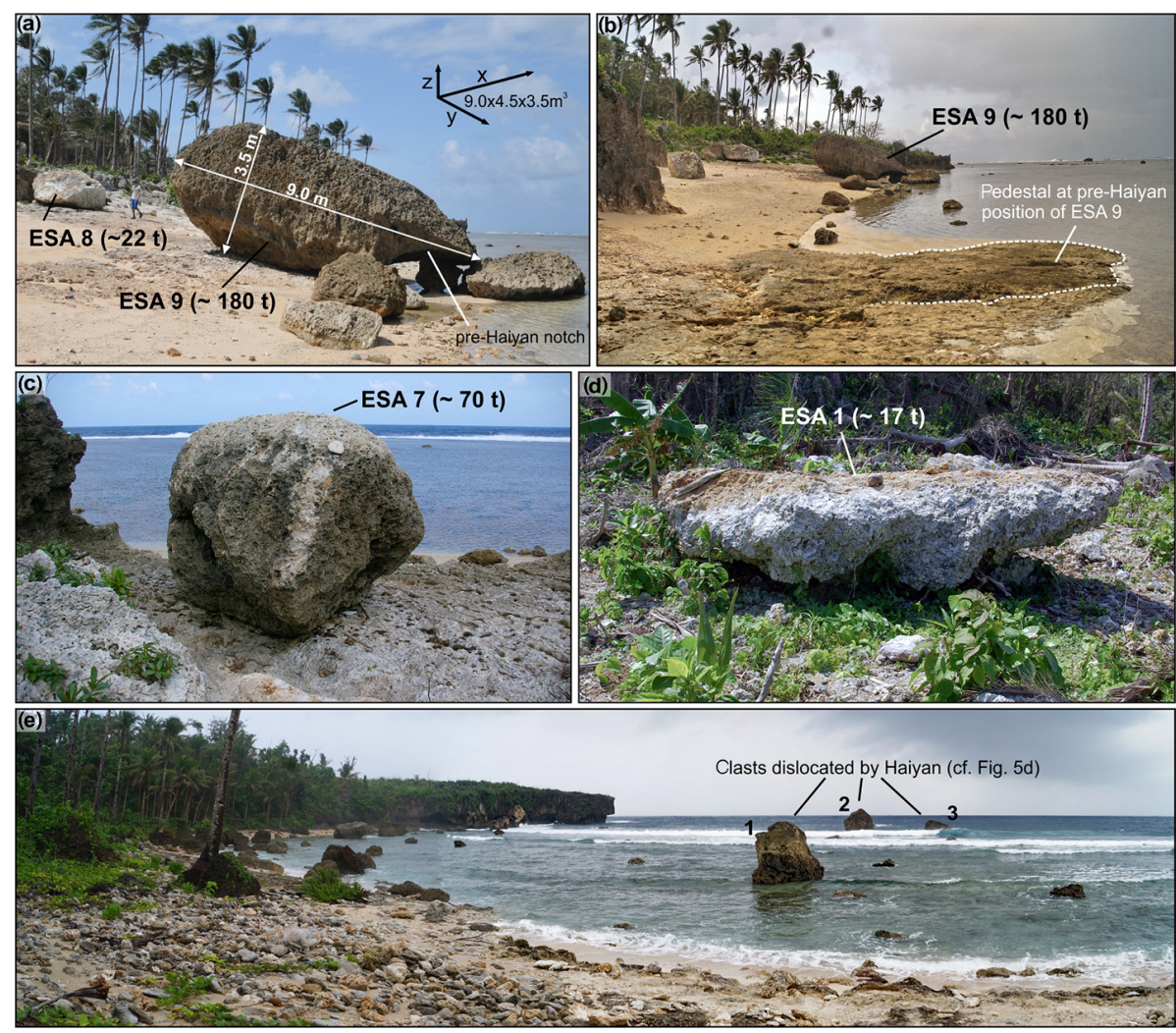

Figure 5. Photos of largest Haiyan-transported clasts at ESA. (a) Photo of ESA 9, the largest clast found at site ESA. (b) A $\sim 5 \mathrm{~cm}$ high pedestal (foreground) was found at the pre-Haiyan position of ESA 9 (background). (c) Photo of ESA 7 looking from the SW towards the lagoon. (d) Boulder ESA 1, situated at 10 m MLLW, directly below the run-up limit. (e) Panorama photo of Nagaha Bay (March 2015); view is to the SSE. Clasts 1-3 were dislocated by Haiyan, as documented by post-Haiyan satellite images (cf. Fig. 4d).

1949) and taking the appropriate $C_{\mathrm{d}}$ values from Fig. 3 in Helley (1969), as suggested by Noormets et al. (2004). For $C_{1}$, coefficient of lift, we used 0.178 according to previous studies (e.g. Nott 1997; Noormets et al. 2004). Finally, we adopted $\mu_{\mathrm{s}}$, coefficient of static friction, of 0.7 according to Nandasena et al. (2011) and the values given for sandcovered limestone platforms in Goto et al. (2007) and Buckley et al. (2012) (Fig. 7, case 1). For each clast, flow velocities were additionally calculated with minimum $C_{1}(0.05)$ and maximum $\mu_{\mathrm{s}}$ (1.02) values provided in previous studies (Nott, 2003; Benner et al., 2010) (Fig. 7, cases 2-4). The equation for the initial transport mode "rolling/overturning" of submerged or subaerial clasts (e.g. ESA 7) reads

$u^{2} \geq \frac{2 \cdot\left(\frac{\rho_{\mathrm{s}}}{\rho_{\mathrm{w}}}-1\right) \cdot g \cdot c \cdot\left(\cos \theta+\frac{c}{b} \cdot \sin \theta\right)}{C_{\mathrm{d}} \cdot \frac{c^{2}}{b^{2}}+C_{1}}$,

whereas the equation for the initial transport mode "saltation/lifting" of clasts in a joint-bounded scenario (e.g. ESA 5) is

$u^{2} \geq \frac{2 \cdot\left(\frac{\rho_{\mathrm{s}}}{\rho_{\mathrm{w}}}-1\right) \cdot g \cdot c \cdot\left(\cos \theta+\mu_{\mathrm{s}} \cdot \sin \theta\right)}{C_{1}}$.
Accordingly, boulder ESA 7 requires minimum flow velocities of $7.6 \mathrm{~m} \mathrm{~s}^{-1}$ to initiate sliding transport and of $8.9 \mathrm{~m} \mathrm{~s}^{-1}$ to initiate rolling transport. For the largest block, ESA 9, initiation of sliding transport requires $7.4 \mathrm{~m} \mathrm{~s}^{-1}$, and flow velocities of $9.6 \mathrm{~m} \mathrm{~s}^{-1}$ would have been required for overturning (Fig. 7, case 1).

On top of the carbonate platform, flow velocities of $6.7 \mathrm{~m} \mathrm{~s}^{-1}$ are necessary for the initial transport with overturning of ESA 1. For boulder ESA 5, which was quarried from the cliff edge (joint-bounded boulder scenario) and must have experienced saltation and lifting during initial transport, flow velocities were calculated to $16 \mathrm{~m} \mathrm{~s}^{-1}$. The boulder transport histogram shown in Fig. 7 illustrates the critical flow velocities necessary for the initiation of different transport modes of each investigated clast.

\subsection{Storm surge and wave model}

While previously published models with a spatial resolution of $2.5 \mathrm{~km}$ resulted in maximum significant wave heights of $>15 \mathrm{~m}$ during Haiyan in deep water off Eastern Samar (Bricker et al., 2014; Fig. 3), maximum significant wave heights of $\sim 4-5 \mathrm{~m}$ and $\sim 5-6 \mathrm{~m}$ are inferred for site ESA and for Hernani, respectively, from the Delft3D model pre- 
Table 2. Boulder axes, volume, and weight of most important clasts at site ESA, Eastern Samar. $T_{1}$ : lateral transport; $T_{\mathrm{V}}$ : vertical transport; $\rho_{\mathrm{b}}$ : bulk density.

\begin{tabular}{|c|c|c|c|c|c|c|c|c|c|c|c|c|c|}
\hline \multirow[t]{2}{*}{ Boulder } & \multirow{2}{*}{$\begin{array}{l}\rho_{\mathrm{b}} \\
\left(\mathrm{g} \mathrm{cm}^{-3}\right)\end{array}$} & \multirow{2}{*}{$\begin{array}{l}T_{1} \\
(\mathrm{~m})\end{array}$} & \multirow{2}{*}{$\begin{array}{l}T_{\mathrm{V}} \\
(\mathrm{m})\end{array}$} & \multicolumn{3}{|c|}{ Dimensions (m) } & \multicolumn{2}{|c|}{ Volume $\left(\mathrm{m}^{3}\right)$} & \multicolumn{2}{|c|}{ Weight $(\mathrm{t})$} & \multirow{2}{*}{$\begin{array}{l}V_{\mathrm{DGPS}} / \\
V_{\mathrm{abc}}\end{array}$} & \multirow{2}{*}{$\begin{array}{l}\text { Corey shape factor } \\
=c / \sqrt{a b} \text { and } \\
\text { boulder-specific } \\
C_{\mathrm{d}}^{\mathrm{b}}\end{array}$} & \multirow[t]{2}{*}{ Remarks } \\
\hline & & & & $a$ axis & $b$ axis & $c$ axis & $V_{\mathrm{abc}}$ & $V_{\text {DGPS }}$ & $W_{\mathrm{abc}}$ & $W_{\text {DGPS }}$ & & & \\
\hline ESA 1 & 2.4 & 20 & 2.5 & 4.6 & 2.3 & 1.1 & 11.6 & 6.9 & 27.9 & 16.7 & 0.60 & $0.34 / 2.1$ & $\begin{array}{l}\text { Highest boulder, now rest- } \\
\text { ing at } 10 \mathrm{~m} \text { MLLW, verti- } \\
\text { cal transport of } 2.5 \mathrm{~m} \text {, over- } \\
\text { turned }\end{array}$ \\
\hline ESA 5 & 2.4 & 40 & 4 & 4.0 & 2.8 & 1.7 & 19.0 & 9.8 & 45.7 & 23.5 & 0.52 & $0.5 / 1.35$ & $\begin{array}{l}\text { Vertical transport of } 4 \mathrm{~m} \text {, } \\
\text { overturned, origin/fracture } \\
\text { plain at } 2 \mathrm{~m} \text { MLLW }\end{array}$ \\
\hline ESA 7 & 2.4 & 35 & - & 5.3 & 3.0 & 2.9 & 46.1 & 28.5 & 110.7 & 68.6 & 0.62 & $0.73 / 0.85$ & $\begin{array}{l}\text { Upper littoral, lateral trans- } \\
\text { port by rolling/saltation, } \\
\text { overturned }\end{array}$ \\
\hline ESA 8 & 2.4 & $>40$ & $>2.5$ & 3.6 & 2.70 & 1.80 & 17.5 & 9.1 & 42.0 & 21.8 & 0.52 & $0.58 / 1.1$ & $\begin{array}{l}\text { Living barnacles and bor- } \\
\text { ing valves (former inter- } \\
\text { tidal), overturned, assumed } \\
\text { vertical transport of at least } \\
2.5 \mathrm{~m}\end{array}$ \\
\hline ESA 9 & 2.4 & 45 & - & 9.00 & 4.50 & 3.50 & 121.5 & $75.3^{\mathrm{a}}$ & 291.6 & $180.8^{\mathrm{a}}$ & $0.62^{\mathrm{a}}$ & $0.55 / 1.4$ & $\begin{array}{l}\text { Largest block, upper inter- } \\
\text { tidal, lateral transport by } \\
\text { sliding }\end{array}$ \\
\hline
\end{tabular}

a $-V_{\text {abc }}$ of ESA 9 was corrected to $V_{\text {DGPS }}$ using a conservative value of 0.6 , which was empirically calculated for the similarly shaped boulder ESA 7;

b - Corey shape factor and appropriate $C_{\mathrm{d}}$ values according to Corey (1949), Helley (1969: Fig. 3), and Komar and Reimers (1978).

sented in this study (Fig. 8a). This is comparable to maximum significant wave heights inferred from recently published higher-resolution Delft3D models off the Holocene reef at Hernani (Bricker and Roeber, 2015).

Combining pressure- and wind-driven surge as well as wave setup, our coupled hydrodynamic and wave model results in slightly elevated maximum water levels $(<1 \mathrm{~m}$ above mean sea level, a.s.l.), and maximum flow velocities below $1.5 \mathrm{~m} \mathrm{~s}^{-1}$ (Fig. 8b, c) at site ESA during Haiyan. Flow velocities at Hernani and in Matarinao Bay already reach high values at 05:30 local time, while maximum flow velocities at ESA are approached at $\sim 08: 00$. However, the modelled water levels are comparable to those inferred from previously published storm surge and FLO2D flood routing models (e.g. Bricker et al., 2014), where still water levels increase to a maximum of $\sim 2.5 \mathrm{~m}$ a.s.l. along the Hernani coast and in Matarinao Bay but remain $<1 \mathrm{~m}$ a.s.l. at site ESA. Most recently, the high-resolution model of Bricker and Roeber (2015) resulted in surge-related maximum still water levels of $4 \mathrm{ma}$ a.s.l. at Hernani and maximum flow speeds of $\sim 3 \mathrm{~m} \mathrm{~s}^{-1}$ off the reef crest; however, flow speeds still rapidly decrease to $<1.5 \mathrm{~m} \mathrm{~s}^{-1}$ on the reef platform and along the coastline, similar to the values presented here (Fig. 8b, c).

\section{Discussion}

\subsection{Boulder transport and flow velocities inferred by inverse modelling}

Based on field evidence, the interpretation of satellite images, and the intensity of previous storms, the documented coarse clast transport can be unambiguously attributed to marine flooding during Haiyan. The size of individual clasts and in particular the dimensions of block ESA 9 $\left(9.0 \times 4.5 \times 3.5 \mathrm{~m}^{3}\right)$, in combination with the documented vertical and lateral transport distances, exceeds any existing literature account, including the often-cited boulder at Sydney's Bondi Beach (Süssmilch, 1912; $6.1 \times 4.9 \times 3.0 \mathrm{~m}^{3}$ ), and clasts moved during TCs in Japan (Goto et al., 2011) and Jamaica (Khan et al., 2010) as well as during Atlantic winter storms (Williams and Hall, 2004; Regnauld et al., 2010; Cox et al., 2012) (Tables 1, 2). According to the pedestal found at its pre-Haiyan position, block ESA 9 was stationary for a considerable period of time prior to Typhoon Haiyan (cf. Matsukura et al., 2007).

The largest transported clasts on the intertidal platform (ESA 7 and 9) show a shore-perpendicular orientation of their longest axis (Fig. 3). Their transport direction, as can be traced by impact marks on the carbonate platform and bitemporal satellite image analysis, documents SE-NW-directed water currents (Fig. 3), coinciding with the modelled flow vectors in the direct vicinity of site ESA (Fig. 8). In contrast, for the rather flat boulders on top of the upper carbonate platform, the orientation of their longest axis is oblique to shore- 

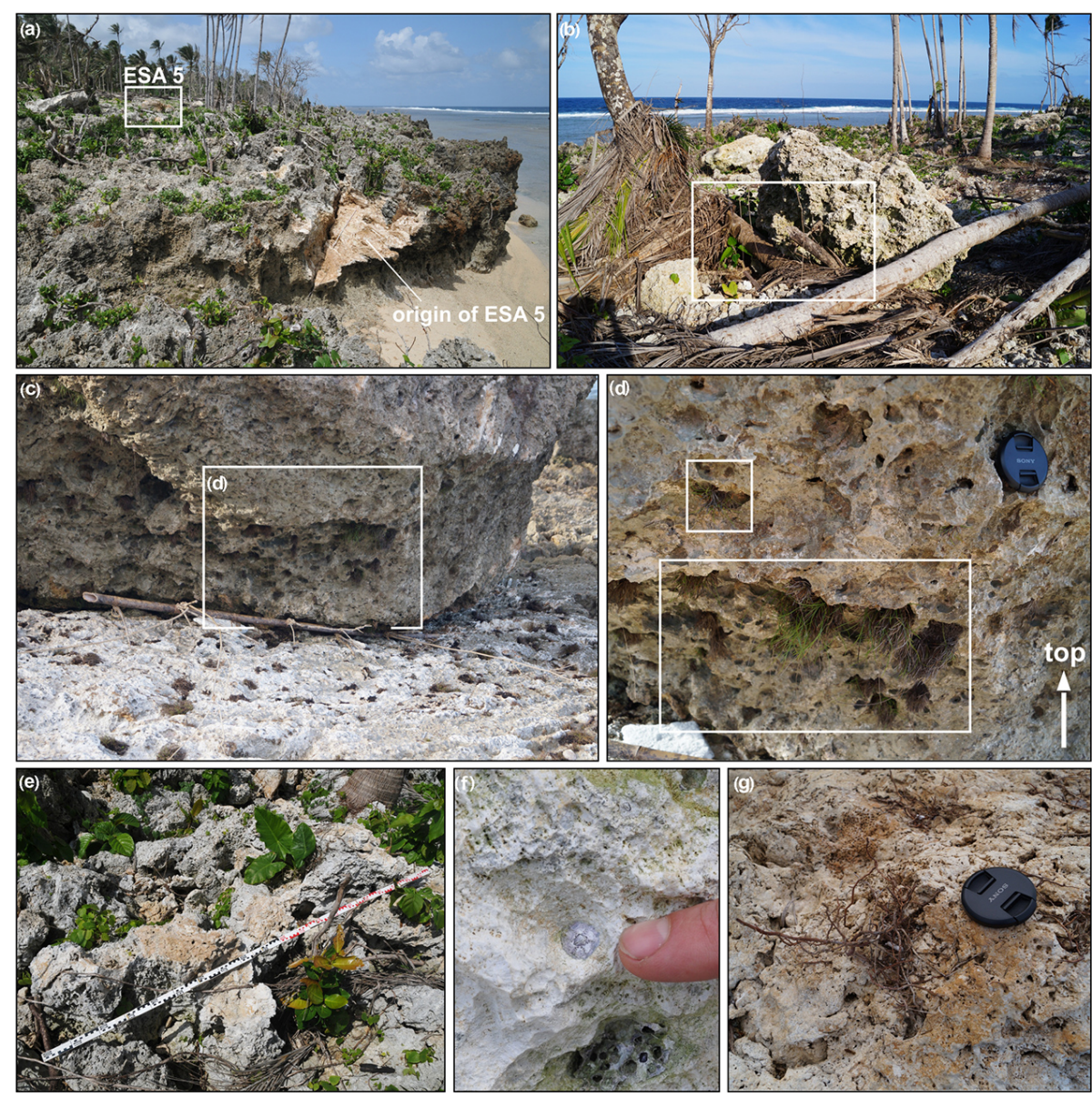

Figure 6. Indicators of boulder movement during Supertyphoon Haiyan. (a) Origin of boulder ESA 5, quarried from the cliff at $\sim 2 \mathrm{~m}$ MLLW and transported upwards and landwards for 4 and $40 \mathrm{~m}$, respectively. Snapped trees and impact marks on the carbonate platform can be traced on its trajectory. (b) Boulder at $6 \mathrm{~m}$ MLLW lying on top of freshly toppled palm trees. (c) Piece of wood jammed under boulder ESA 7. (d) Downward-facing and decaying grass patches at the former surface and new bottom side of ESA 7. (e) Percussion marks on the Pleistocene carbonate platform, tracing the transport track of ESA 5. Scale is $2 \mathrm{~m}$. (f) Still-living barnacle attached to boulder ESA 8, situated at $2.5 \mathrm{~m}$ MLLW, i.e. clearly above highest tide levels. (g) Roots and soil staining on the exposed former bottom side of several boulders (here boulder ESA 1) provide evidence of overturning during Haiyan.

parallel (Fig. 3), suggesting alignment to approaching superimposed storm waves and/or deflection of water currents on top of the reef platform by the $\sim 2 \mathrm{~m}$ high cliff.

Compared to previously published low-resolution models (Bricker et al., 2014; Fig. 3) and to wave heights generally expected during catastrophic typhoons such as Haiyan, our model apparently results in underestimated maximum significant wave heights offshore of Eastern Samar. These discrepancies may particularly be explained by the different typhoon track data used in this study, with 1 min sustained winds implemented in the JTWC track. However, the timing of maximum significant wave heights in our model is generally in agreement with the timing of the catastrophic flooding at Hernani, which was video-captured at $\sim 06: 00$ PHT. According to our model, highest waves developed at $\sim 05: 20$ PHT (depicted in Fig. 8a) and lasted until $\sim 06: 00$ PHT, while highest flow velocities at site ESA (due to pressure- and wind-driven setup) occurred delayed (Fig. 8b, c). This corroborates results presented by Roeber and Bricker (2015), stating that modelled offshore wave heights dropped rapidly after 06:00 PHT, while pressure- and wind-induced setup remained high.

However, despite the discrepancies and similarities mentioned above, flow velocities modelled with Delft3D in this study and in all previous studies are insufficient to account for the transport of the documented clasts (Fig. 8; see also Bricker et al., 2014; Bricker and Roeber, 2015). For the rather spherical boulder ESA 7, a rolling transport mode was inferred from the field observations requiring at least $8.9 \mathrm{~m} \mathrm{~s}^{-1}$ for the initiation of movement (Fig. 7, case 1) when assuming no vertical component in the transport track $(\theta=0.5)$. In contrast, a sliding transport mode due to flow velocities higher than $\sim 7.4 \mathrm{~m} \mathrm{~s}^{-1}$ but below $\sim 9.6 \mathrm{~m} \mathrm{~s}^{-1}$ is assumed 


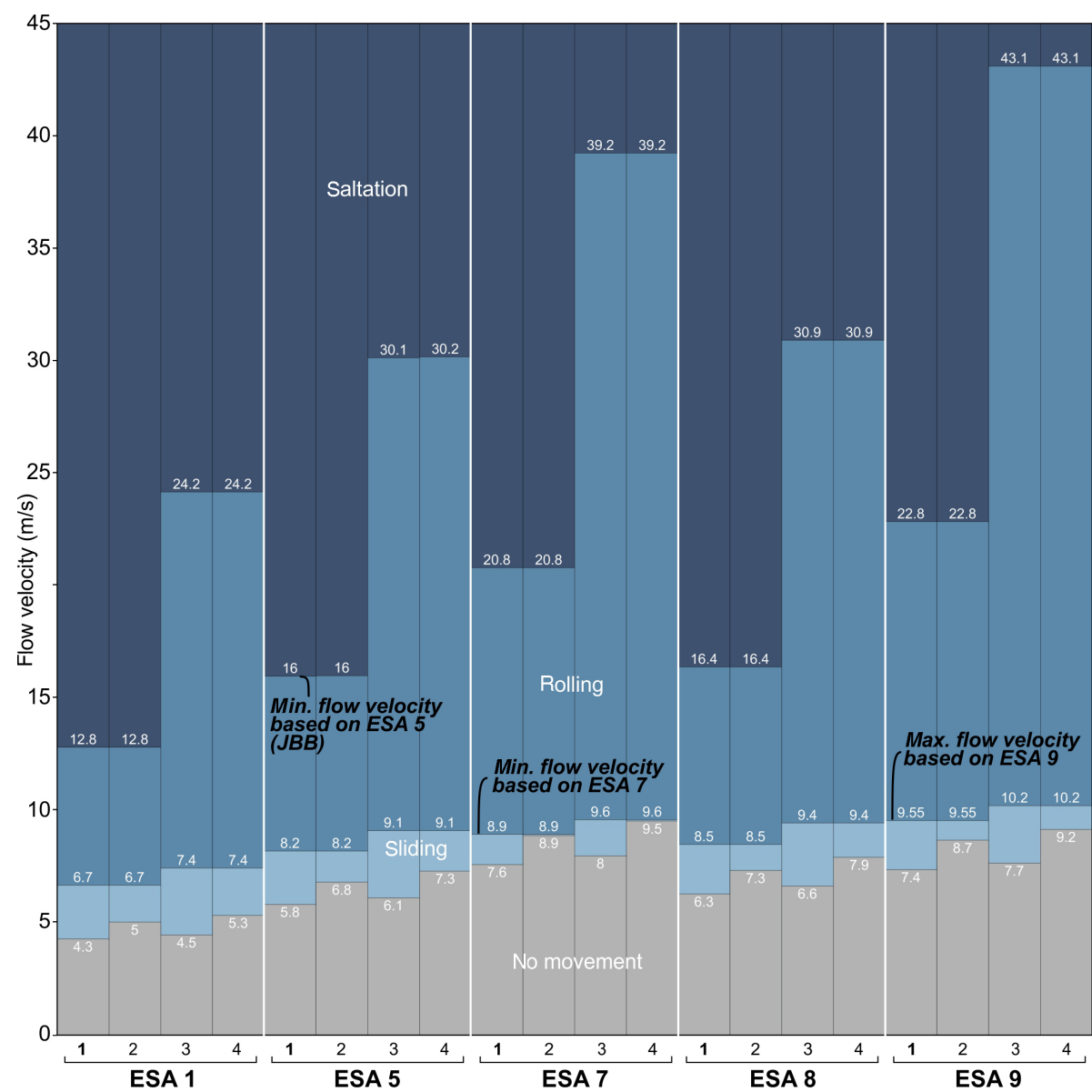

Figure 7. Flow velocities calculated for transport of largest clasts at site ESA. For each clast, flow velocities were calculated with different coefficients taken from the literature (cases $1-4$ on $x$ axis): $1-C_{1}=0.178, \mu=0.7 ; 2-C_{1}=0.178, \mu=1.02 ; 3-C_{1}=0.05, \mu=0.7 ; 4-$ $C_{1}=0.05, \mu=1.02$ (Nott, 2003; Noormets et al., 2004; Benner et al., 2010; Nandasena et al., 2011). For case 1, minimum flow velocities of $8.9 \mathrm{~m} \mathrm{~s}^{-1}$ were calculated for ESA 7 using Eq. (2) to initiate rolling movement as observed in the field. Since no signs for overturning were documented for ESA 9, flow velocities are assumed to have remained below $9.55 \mathrm{~m} \mathrm{~s}^{-1}$ based on Eq. (1). However, based on Eq. (3) of Nandasena et al. (2011), quarrying of ESA 5 required flow velocities of $>16 \mathrm{~m} \mathrm{~s}^{-1}$. In comparison to case 1 , flow velocities calculated for cases $2-4$ differ in the order of $1.0-1.9 \mathrm{~m} \mathrm{~s}^{-1}$ (for the initiation of sliding) and $0.7-0.9 \mathrm{~m} \mathrm{~s}^{-1}$ (for the initiation of rolling). Remarkably higher flow velocities for the initiation of saltation are calculated with $C_{1}=0.05$ (cases 3 and 4 ).

for dislocation of the largest block ESA 9 since no signs of overturning were observed.

While these flow velocities are based on boulder-specific $C_{\mathrm{d}}$ values, uncertainties remain in terms of realistic (boulderand site-specific, respectively) values for $C_{1}$ and $\mu_{\mathrm{s}}$. In addition to $\mu_{\mathrm{s}}=0.7$ (Noormets et al., 2004; Paris et al., 2010; Nandasena et al., 2011) values between 0.6 or 0.65 and 0.8 (Goto et al., 2007; Benner et al.; 2010; Buckley et al., 2012) or between 0.82 and 1.02 (Nott, 2003; based on empirical studies of Fukui et al., 1963) have been suggested, most of them in the context of sand-covered limestone platforms. While changes in the calculated flow velocities for sliding transport mode are negligible with $\mu_{\mathrm{s}}=0.6$, notable changes are particularly recognized when applying the maximum values given by Nott (2003): with $\mu_{\mathrm{s}}=1.02$, up to $1.9 \mathrm{~m} \mathrm{~s}^{-1}$ higher flow velocities are necessary to initiate slid- ing of ESA 7 and ESA 9 (Fig. 7, cases 2 and 4). For $C_{1}$, realistic values range between 0.05 and 0.2 according to Benner et al. (2010), with 0.2 being very close to the one used in case 1 of this study (Fig. 7) and in previous studies (0.178; Nott, 2003; Noormets et al., 2004; Paris et al., 2010; Nandasena et al., 2011). The minimum value for $C_{1}(0.05)$ results in slightly increased flow velocities (i.e. $<0.9 \mathrm{~m} \mathrm{~s}^{-1}$ higher) for rolling/sliding of ESA 7 and 9 (Fig. 7, cases 3 and 4), and considerably increased flow velocities (up to $\sim 20 \mathrm{~m} \mathrm{~s}^{-1}$ ) for saltation/lifting.

Consequently, the flow velocities calculated for case 1 represent conservative (i.e. minimum) values, and flow speeds at this study site most probably exceeded $8.9 \mathrm{~m} \mathrm{~s}^{-1}$ but remained below $9.6 \mathrm{~m} \mathrm{~s}^{-1}$. Calculated flow velocities for these clasts are thus in the range of or even higher than those in- 

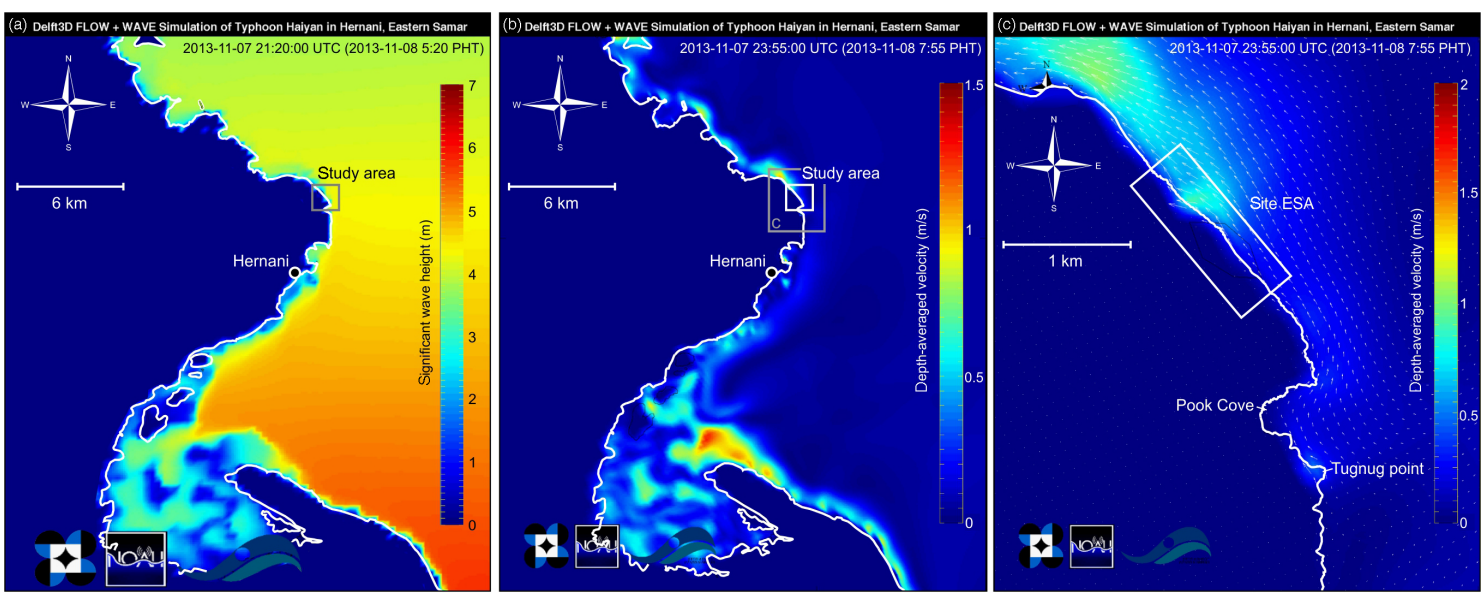

Figure 8. Results from the (phase-averaged) wave and storm surge model using Delft3D and Delft Dashboard software. (a) Maximum significant wave heights in Eastern Samar. Based on our model, maximum significant waves heights reached ca. 4-5 m at $\sim 05: 20$ PHT in the study area. However, wave heights seem to be underestimated when compared to previously published low-resolution models (Bricker et al., 2014; Fig. 3). (b, c) Even in the coupled hydrodynamic and wave model, combining pressure- and wind-driven surge as well as wave setup, the maximum depth-averaged flow velocities calculated for Eastern Samar (b) and the study area (c) remain below $1.5 \mathrm{~m} \mathrm{~s}{ }^{-1}$. Highest velocities at ESA are approached at $\sim$ 08:00 PHT. PHT - Philippine Time; UTC - Coordinated Universal Time.

ferred for recent major tsunamis at the coast (Fritz et al., 2006, 2012).

Based on the applied formula, quarrying of ESA 5 from the cliff edge, as documented by the field survey, requires flow velocities of at least $\sim 16 \mathrm{~m} \mathrm{~s}^{-1}$ (Fig. 7). Since these flow velocities would have caused rolling transport of ESA 9 , ambiguities remain for the joint-bounded boulder scenario, which tends towards significant overestimation (Switzer and Burston, 2010; Etienne, 2012). Discrepancies may for instance be related to the overestimation of strain forces between the block and the strongly karstified reef body, or to the underestimation of the waves' impact and lift forces approaching the cliffs and their associated jets (Hansom et al., 2008). However, flow velocities of $8.2 \mathrm{~m} \mathrm{~s}^{-1}$ are required for the subsequent rolling transport of ESA 5, which is in agreement with the flow velocities inferred from ESA 7 and 9. Against the background of previously published models (Bricker and Roeber, 2015; Roeber and Bricker, 2015) and the modelled low flow velocities presented here, it is apparent that hydrodynamic processes have to be considered for the dislocation of the ESA clasts, which are beyond storm surge and incident waves.

\subsection{Origin of exceptional flooding pattern}

A very high velocity of the typhoon over the NW Pacific $\left(32 \mathrm{~km} \mathrm{~h}^{-1}\right)$, an unusually warm subsurface ocean layer, and a long travel distance over the open ocean $(3000 \mathrm{~km})$ (Normile, 2013; Pun et al., 2013) probably provided the momentum for Hayian's exceptional storm surge. For the Leyte Gulf and in particular San Pedro Bay off Tacloban, Mori et al. (2014) conclude that amplification of storm surge-induced water levels was due to seiches, also provoking the specific inundation pattern of distinct flooding pulses observed by residents.

In contrast, wind- and pressure-driven storm surge along the SE Samar coast is believed to not have exceeded $\sim 1 \mathrm{~m}$ due to the steep slope off the coast, but setup by breaking waves locally induced water levels of up to $\sim 2.5 \mathrm{~m}$ such as on top of the broad Holocene reef platforms (see also Bricker et al., 2014) or even $4 \mathrm{~m}$ at Hernani (Bricker and Roeber, 2015). However, in all phase-averaged (e.g. Delft3D/SWANbased) coupled wave and storm surge models considering breaking-wave setup, including the here-presented one, modelled flow velocities on top and landward of the reef platform remain $<1.5 \mathrm{~m} \mathrm{~s}^{-1}$ (cf. Bricker and Roeber, 2015) and thus remarkably below those required for the clast transport documented at ESA during Haiyan.

To explain the surprisingly high inundation levels in SE Samar (Tajima et al., 2014) and the bore-like coastal flooding captured at Hernani (Mas et al., 2015), Bricker et al. (2014) hypothesized that infragravity waves (such as surf beat) (Munk, 1950) were caused by non-linear wave interactions with the reef, which are not resolved by the existing Delft3D and SWAN models. A Haiyan-related meteo-tsunami can be excluded due to a lack of bathymetric conditions with suitable resonance properties. Most recently, based on models simulating wave transformation over shallow fringing reefs using Boussinesq-type equations, Shimozono et al. (2015) and Roeber and Bricker (2015) confirmed that the extreme run-ups and the bore-like flooding pattern in Eastern Samar must be explained by strong coupling of sea swells and infragravity waves with periods of $>1 \mathrm{~min}$, which may have experienced excitation by resonances with the fringing reef (cf. Péquignet et al., 2009). These models inferred flow 
speeds $>5 \mathrm{~m} \mathrm{~s}^{-1}$ at the video site in Hernani, which is in good agreement with the flow speeds derived from (i) the video footage at Hernani onshore (up to $6 \mathrm{~m} \mathrm{~s}^{-1}$; Bricker and Roeber, 2015) and (ii) initiation-of-motion criteria of the coarse-clast record presented in this study. Since pressureand wind-induced setup occurred delayed with respect to maximum offshore wave heights (Roeber and Bricker, 2015; Fig. 8c), the most destructive infragravity waves developed only within a short time frame, before offshore wave heights rapidly dropped after $\sim 06: 00$ PHT (Roeber and Bricker, 2015).

Surf beat resulting in pulses of elevated water depths and flow velocities is thus assumed to be the driving process for the transport of the investigated boulders some $4 \mathrm{~km}$ north of the Hernani video site. Although the NW-directed longshore currents, as documented by the shore-parallel trajectories of ESA 7 and 9, agree with the modelled flow vectors of wind- and pressure-driven storm surge, surf-beat-generated currents deviating from a shore-normal direction, and/or the deflection of these currents along the cliffs, must be assumed for the study area. However, regardless of the mechanisms responsible for the exceptional coastal flooding pattern, the sedimentary findings presented here give striking evidence of very high run-up and strong wave- and surge-accompanying sustained currents along the coast of SE Samar during Supertyphoon Haiyan. They were capable of transporting blocksized clasts over horizontal distances of up to $\sim 40 \mathrm{~m}$ and producing spatially randomized clast distributions, both of which are often associated with tsunami deposition.

\section{Conclusions}

Based on their SE-NW trajectory and a surge-perpendicular orientation of their longest axis (Fig. 3), we conclude that the exceptional flooding pattern, caused by wave setup and infragravity waves, induced the transport of the largest clasts rather than the high breaking waves alone. This is in contrast to many previous observations and descriptions of stormmoved boulders, which are defined to be "wave-transported" (Table 1). However, the shore-parallel orientation of the slabshaped boulders on top of the carbonate platform may suggest that superimposed waves, having reached heights of more than $5 \mathrm{~m}$ (Bricker et al., 2014), contributed to their trajectory as well. The remarkable flooding pattern videocaptured at Hernani thus affected a wider coastal section, i.e. $\sim 5 \mathrm{~km}$ to the north, and was not restricted to special boundary conditions in urbanized areas such as sea wall structures at Hernani.

Supported by post-typhoon survey reports (Bricker et al., 2014; Tajima et al., 2014), recent wave models (Roeber and Bricker, 2015; Shimozono et al., 2015), eyewitness accounts, and video footage (Mas et al., 2015; Bricker and Roeber, 2015), our findings suggest that a variety of hydrodynamic processes related to TC landfall must be considered when interpreting boulder deposits along coasts. These processes may include, in addition to incident (potentially very high) gravity waves and (or on top of) pressure- and wind-driven storm surge, meteo-tsunamis or seiches (Mori et al., 2014), as well as infragravity waves with periods of up to several minutes. The sustained high-velocity coastal flooding resulting from these infragravity waves, in combination with inundation depths of several metres, is capable of transporting clasts similar to palaeo-deposits commonly related to tsunamis. This is in agreement with theory-based conclusions of Weiss (2012) that both tsunamis and storms may shift clasts of comparable sizes. Our conclusions have important implications for the interpretation of coastal block and boulder deposits and numerical simulations of their transport in similar settings. Where storms have previously been ruled out as being the cause of the dislocation and transport of very large clasts based on their dimensions, the geological legacy of Haiyan prompts the need for a careful reconsideration of possible storm-related transport.

Author contributions. S. M. May, D. Brill, M. Engel, M. Reyes, and $\mathrm{H}$. Brückner contributed to field and lab work. S. M. May, D. Brill, M. Engel, and H. Brückner designed the study and interpreted the data. Modelling was done by C. Cuadra, A. M. F. Lagmay, J. Santiago, and J. K. Suarez. Finally, S. M. May, D. Brill, and M. Engel wrote the manuscript.

Acknowledgements. Financial support for the research is granted by the Faculty of Mathematics and Natural Sciences, University of Cologne (UoC), and a UoC postdoc grant. Invaluable logistic support was provided by Karen Tiopes and Verna Vargas (Department of Tourism, Leyte Branch). Kirstin Jacobson is acknowledged for language editing, and Jan Oetjen (RWTH Aachen) for the evaluation of the storm surge model. Mark A. C. Bahala, Lia A. L. Gonzalo (both Project NOAH), Eva Quix (UoC), and Bastian Schneider (German International Cooperation (GIZ)) kindly supported boulder mapping. We are very appreciative of the great hospitality considering the situation left by the disaster and of first-hand insights by local interviewees throughout the Visayas archipelago.

Edited by: J. Turowski

\section{References}

Barrier, E., Huchon, P., and Aurelio, M.: Philippine fault: a key for Philippine kinematics, Geology, 19, 32-35, 1991.

Benner, R., Browne, T., Brückner, H., Kelletat, D., and Scheffers, A.: Boulder Transport by Waves: Progress in Physical Modelling, Z. Geomorphol., 54, Suppl. 3, 127-146, 2010.

Boyson, H.: Photo taken and provided by Henry Boyson, available at: http://www.panoramio.com/photo/82283313?source= wapi\&referrer=kh.google.com (last access: 28 November 2015), 2012. 
Bricker, J. and Roeber, V.: Mechanisms of damage during Typhoon Haiyan: storm surge, waves, and "tsunami-like" surf beat, Eproceedings of the 36th IAHR World Congress, 28 June-3 July, 2015, The Hague, the Netherlands, 2015.

Bricker, J., Takagi, H., Mas, E., Kure, S., Adriano, B., Yi, C., and Roeber V.: Spatial variation of damage due to storm surge and waves during Typhoon Haiyan in the Philippines, Journal of the Japan Society of Civil Engineers, Series B2, 70, 231-235, 2014.

Buckley, M. L., Wei, Y., Jaffe, B. E., and Watt, S. G.: Inverse modeling of velocities and inferred cause of overwash that emplaced inland fields of boulders at Anegada, British Virgin Islands, Nat. Hazards, 63, 133-149, 2012.

Cass, L.: Exploding The Myth - The Big Rock. The Bondi View 7, available at: http://www.cyberbondi.com.au/v3/bondiview_1. html (last access: 28 November 2015), 2002.

Corey, A. T.: Influence of shape on fall velocity of sand grains. Unpublished MSc thesis, Colorado A\&M College, Colorado, USA, 102 pp., 1949.

Corral, A., Ossó, A., and Llebot, J. E.: Scaling of tropical-cyclone dissipation, Nat. Phys., 6, 693-696, 2010.

Cox, R., Zentner, D. B., Kirchner, B. J., and Cook, M. S.: Boulder ridges on the Aran Islands (Ireland): Recent movements caused by storm waves, not tsunamis, J. Geol., 120, 249-272, 2012.

Cuadra, C., Biton, N. I., Cabacaba, K. M., Santiago, J., Suarez, J. K., Lapidez, J. P., Lagmay, A. M. F., and Malano, V.: Development of Inundation Map for Bantayan Island, Cebu Using Delft3D-Flow Storm Surge Simulations of Typhoon Haiyan, NOAH Open-File Reports, 3, 37-44, 2014.

Engel, M. and May, S. M.: Bonaire's boulder fields revisited: Evidence for Holocene tsunami impact on the Leeward Antilles, Quaternary Sci. Rev., 54, 126-141, 2012.

Etienne, S.: Marine inundation hazards in French Polynesia: geomorphic impacts of Tropical Cyclone Oli in February 2010, Geol. Soc. Spec. Publ., 361, 21-39, 2012.

Etienne, S., Buckley, M., Paris, R., Nandasena, A. K., Clark, K., Strotz, L., Chagué-Goff, C., Goff, J., and Richmond, B.: The use of boulders for characterizing past tsunamis: lessons from the 2004 Indian Ocean and 2009 South Pacific tsunamis, Earth-Sci. Rev., 107, 76-90, 2011.

Felton, E. A. and Crook, K. A. W.: Evaluating the impacts of huge waves on rocky shorelines: an essay review of the book "Tsunami - The Underrated Hazard”, Mar. Geol., 197, 1-12, 2003.

Fritz, H. M., Borrero, J. C., Synolakis, C. E., and Yoo, J.: 2004 Indian Ocean tsunami flow velocity measurements from survivor videos, Geophys. Res. Lett., 33, L24605, doi:10.1029/2006GL026784, 2006.

Fritz, H. M., Blount, C. D., Thwin, S., Kyaw Thu, M., and Chan, N.: Cyclone Nargis storm surge in Myanmar, Nat. Geosci., 2, 448-449, 2009.

Fritz, H. M., Phillips, D. A., Okayasu, A., Shimozono, T., Liu, H., Mohammed, F., Skanavis, V., Synolakis, C. E., and Takahashi, T.: The 2011 Japan tsunami current velocity measurements from survivor videos at Kesennuma Bay using LiDAR, Geophys. Res. Lett., 39, L00G23, doi:10.1029/2011GL050686, 2012.

Fukui, Y.; Nakamura, M., Shiraishi, H., and Sasaki,Y.: Hydraulic study on tsunami: Coastal Engineering in Japan, 6, 67-82, 1963.

Gensis, N.: Eyewitness footage of Typhoon Haiyan washing house away; video taken at Hernani, Eastern Samar, at 6 am, 8 November 2013 by Nickson Gensis, Plan Philippines Community De- velopment Worker, available at: http://www.youtube.com/watch? v=rS0gv4Xbw7w (last access: 28 November 2015), 2013.

Gienko, G. A. and Terry, J. P.: Three-dimensional modeling of coastal boulders using multi-view image measurements, Earth Surf. Proc. Land., 39, 853-864, 2014.

Google Earth/Digital Globe: Bondi Beach, Australia. $33.893723^{\circ} \mathrm{S}$, $151.282965^{\circ} \mathrm{W}$, Eye alt $220 \mathrm{~m}$. Image taken on 11 March 2007, available at: http://www.earth.google.com,last access: 28 November 2015.

Goto, K., Chavanich, S. A., Imamura, F., Kunthasap, P., Matsui, T., Minoura, K., Sugawara, D., and Yanagisawa, H.: Distribution, origin and transport process of boulders deposited by the 2004 Indian Ocean tsunami at Pakarang Cape, Thailand, Sediment. Geol., 202, 821-837, 2007.

Goto, K., Miyagi, K., Kawamata, H., and Imamura, F.: Discrimination of boulders deposited by tsunamis and storm waves at Ishigaki Island, Japan, Mar. Geol., 269, 34-45, 2010.

Goto, K., Miyagi, K., Kawana, T., Takahashi, J., and Imamura, F.: Emplacement and movement of boulders by known storm waves - Field evidence from the Okinawa Islands, Japan, Mar. Geol., 283, 66-78, 2011.

Hansom, J. D., Bartrop, N. D. P., and Hall, A. M.: Modelling the processes of cliff-top erosion and deposition under extreme storm waves, Mar. Geol., 253, 36-50, 2008.

Helley, E. J.: Field measurement of the initiation of large bed particle motion in blue creek near Klamath, California, U.S. Geological Survey Professional Paper, 562-G, 1969.

Hoffmann, G., Reicherter, K., Wiatr, T., Grützner, C., and Rausch, T.: Block and boulder accumulations along the coastline between Fins and Sur (Sultanate of Oman): tsunamigenic remains?, Nat. Hazards, 65, 851-873, 2013.

Hoffmeister, D., Ntageretzis, K., Aasen, H., Curdt, C., Hadler, H., Willershäuser, T., Bareth, G., Brückner, H., and Vött, A.: 3D model-based estimations of volume and mass of high-energy dislocated boulders in coastal areas of Greece by terrestrial laser scanning, Z. Geomorphol., 58, Suppl. 3, 115-135, 2014.

Holland, G. J.: An analytic model of the wind and pressure profiles in hurricanes, Mon. Weather Rev., 108, 1212-1218, 1980.

Hughes, T. P.: Skeletal density and growth form of corals, Mar. Ecol.-Prog. Ser., 35, 259-266, 1987.

IRIDeS (International Research Institute of Disaster Science): Initial Report of IRIDeS fact-finding mission to Philippines, TOHOKU University, Sendai, Japan, 2014.

JTWC: 1984 Annual Tropical Cyclone Report. U. S. Naval Oceanography Command Center/Joint Typhoon Warning Center, Guam, available at: http://www.usno.navy.mil/NOOC/nmfc-ph/ RSS/jtwc/atcr/1984atcr.pdf (last access: 28 November 2015), 1985.

JTWC: 2013 Annual Tropical Cyclone Report. U. S. Naval Oceanography Command Center/Joint Typhoon Warning Center, Guam, available at: http://www.usno.navy.mil/NOOC/nmfc-ph/ RSS/jtwc/atcr/2013atcr.pdf (last access: 28 November 2015), 2014.

Khan, S., Robinson, E., Rowe, D.-A., and Coutou, R.: Size and mass of shoreline boulders moved and emplaced by recent hurricanes, Jamaica, Z. Geomorphol., 54, Suppl. 3, 281-299, 2010.

Komar, P. D. and Reimers, C. E.: Grain Shape Effects on Settling Rates, J. Geol., 86, 193-209, 1978. 
Lagmay, A. M. F., Agaton, R. P., Bahala, M. A., Briones, J. B. L. T., Cabacaba, K. M. C., Caro, C. V. C., Dasallas, L. L., Gonzalo, L. A. L., Ladiero, C. N., Lapidez, J. P., Mungcal, M. T. F., Puno, J. V. R., Ramos, M. M. A. C., Santiago, J., Suarez, J. K., and Tablazon, J. P.: Devastating storm surges of Typhoon Haiyan, International Journal of Disaster Risk Reduction, 11, 1-12, 2015.

Lapidez, J. P., Tablazon, J., Dasallas, L., Gonzalo, L. A., Cabacaba, K. M., Ramos, M. M. A., Suarez, J. K., Santiago, J., Lagmay, A. M. F., and Malano, V.: Identification of storm surge vulnerable areas in the Philippines through the simulation of Typhoon Haiyan-induced storm surge levels over historical storm tracks, Nat. Hazards Earth Syst. Sci., 15, 1473-1481, doi:10.5194/nhess-15-1473-2015, 2015.

Lorang, M. S.: A wave-competence approach to distinguish between boulder and megaclast deposits due to storm waves versus tsunamis, Mar. Geol., 283, 90-97, 2011.

Maeda, Y., Siringan, F., Omura, A., Berdin, R., Hosono, Y., Atsumi, S., and Nakamura, T.: Higher-than-present Holocene mean sea levels in Ilocos, Palawan and Samar, Philippines, Quatern. Int., 115-116, 15-26, 2004.

Maragos, J. E., Baines, G. B. K., and Beveridge, P. J.: Tropical Cyclone Bebe creates a new land formation on Funafuti Atoll, Science, 181, 1161-1164, 1973.

Mas, E., Bricker, J., Kure, S., Adriano, B., Yi, C., Suppasri, A., and Koshimura, S.: Field survey report and satellite image interpretation of the 2013 Super Typhoon Haiyan in the Philippines, Nat. Hazards Earth Syst. Sci., 15, 805-816, doi:10.5194/nhess15-805-2015, 2015.

Matsukura, Y., Maekado, A., Aoki, H., Kogure, T., and Kitano, Y.: Surface lowering rates of uplifted limestone terraces estimated from the height of pedestals on a subtropical island of Japan, Earth Surf. Proc. Land., 32, 1110-1115, 2007.

Mori, N., Kato, M., Kim, S., Mase, H., Shibutani, Y., Takemi, T., Tsuboki, K., and Yasuda, T.: Local amplification of storm surge by Super Typhoon Haiyan in Leyte Gulf, Geophys. Res. Lett., 41, 5106-5113, 2014.

Munk, W. H.: Origin and generation of waves, Coastal Engineering Proceedings, 1, 1-4, 1950.

Nandasena, N. A. K., Paris, R., and Tanaka, N.: Reassessment of hydrodynamic equations: Minimum flow velocity to initiate boulder transport by high energy events (storms, tsunamis), Mar. Geol., 281, 70-84, 2011.

NDRRMC, Republic of the Philippines, National Disaster Risk Reduction and Management Council: SitRep No. 108 Effects of Typhoon "YOLANDA" (HAIYAN), available at: http://www. ndrrmc.gov.ph/attachments/article/1329/Effects_of_Typhoon_ YOLANDA_(HAIYAN)_SitRep_No_108_03APR2014.pdf (last access: 28 November 2015), 2014a.

NDRRMC, Republic of the Philippines, National Disaster Risk Reduction and Management Council: SitRep No. 09 Effects of Tropical storm BASYANG (KAJIKI), available at: http://reliefweb.int/sites/reliefweb.int/files/resources/ UPDreSitRep9EffectsTSBasyang(06FEB2014).pdf (last access: 28 November 2015), 2014b.

Noormets, R., Crook, K. A. W., and Felton, E. A.: Sedimentology of rocky shorelines: 3. Hydrodynamics of megaclast emplacement and transport on a shore platform, Oahu, Hawaii, Sediment. Geol., 172, 41-65, 2004.
Normile, D.: Clues to supertyphoon's ferocity found in the Western Pacific, Science, 342, p. 1027, 2013.

Nott, J.: Extremely high-energy wave deposits inside the Great Barrier Reef, Australia: determining the cause - tsunami or tropical cyclone, Mar. Geol., 141, 193-207, 1997.

Nott, J.: Waves, coastal boulder deposits and the importance of the pre-transport setting, Earth Planet. Sc. Lett., 210, 269-276, 2003.

Omura, A., Maeda, Y., Kawana, T., Siringan, F. P., and Berdin, R. D.: U-series dates of Pleistocene corals and their implications to the paleo-sea levels and the vertical displacement in the Central Philippines, Quatern. Int., 115-116, 3-13, 2004.

Paris, R., Fournier, J., Poizot, E., Etienne, S., Morin, J., Lavigne, F., and Wassmer, P.: Boulder and fine sediment transport and deposition by the 2004 tsunami in Lhok Nga (western Banda Aceh, Sumatra, Indonesia): A coupled offshore-onshore model, Mar. Geol., 268, 43-54, 2010.

Péquignet, A. C. N., Becker, J. M., Merrifield, M. A., and Aucan, J.: Forcing of resonant modes on a fringing reef during tropical storm Man-Yi, Geophys. Res. Lett., 36, L03607, doi:10.1029/2008GL036259, 2009.

Philippine Weather Bureau: The Typhoon of Samar, Leyte and Panay, November 24 and 25, 1912, Meteorological Bulletin of the Philippine Weather Bureau, November 1912, 391-402, 1912.

Pun, I.-F., Lin, I.-I., and Lo, M.-H.: Recent increase in high tropical cyclone heat potential area in the Western North Pacific Ocean, Geophys. Res. Lett., 40, 4680-4684, 2013.

Quinto, R. Z., Tuazon, W. H., Moron, L., and Cuenca, R.: Storm surge occurrences during the passage of Typhoon Yolanda on November 8, 2013 in selected areas of Leyte and Samar, Unpublished report of the PAGASA stride team, 33 pp., 2014.

Ramos, N. and Tsutsumi, H.: Evidence of large prehistoric offshore earthquakes deduced from uplifted Holocene marine terraces in Pangasinan Province, Luzon Island, Philippines, Tectonophysics, 495, 145-158, 2010.

Regnauld, H., Oszwald, J., Planchon, O., Pignatelli, C., Piscitelli, A., Mastronuzzi, G., and Audevard, A.: Polygenetic (tsunami and storm) deposits? A case study from Ushant Island, western France, Z. Geomorphol., 54, Suppl. 3, 197-217, 2010.

Richmond, B. M., Watt, S., Buckley, M., Jaffe, B., Gelfenbaum, G., and Morton, R. A.: Recent storm and tsunami coarseclast deposit characteristics, southeast Hawaii, Mar. Geol., 283, 79-89, 2011. Roeber, V. and Bricker, J. D.: Destructive tsunami-like wave generated by surf beat over a coral reef during Typhoon Haiyan, Nature Communications, 6, 7854, doi:10.1038/ncomms8854, 2015.

Scheffers, S. R., Scheffers, A., Kelletat, D., and Bryant, E. A.: The Holocene paleo-tsunami history of West Australia, Earth Planet. Sc. Lett., 270, 137-146, 2008.

Scicchitano, G., Monaco, C., and Tortorici, L.: Large boulder deposits by tsunami waves along the Ionian coast of south-eastern Sicily (Italy), Mar. Geol., 238, 75-91, 2007.

Shimozono, T., Tajima, Y., Kennedy, A. B., Nobuoka, H., Sasaki, J., and Sato, S.: Combined infragravity wave and sea-swell runup over fringing reefs by super typhoon Haiyan, J. Geophys. Res.Oceans, 120, 4463-4486, 2015.

Soria, J. L. A., Switzer, A. D., Villanoy, C. L., Fritz, H. M., Bilgera, P. H. T., Cabrera, O. C., Siringan, F. P., Maria, Y.-S., Ramos, R. D., and Fernandez, I. Q.: Repeat storm surge disasters of Typhoon Haiyan and its 1897 predecessor in the Philippines, 
B. Am. Meteorol. Soc., doi:10.1175/BAMS-D-14-00245.1, in press, 2015.

Süssmilch, C. A.: Note on some recent marine erosion at Bondi, Journal Proceedings of the Royal Society of New South Wales, 46, 155-158, 1912.

Switzer, A. D. and Burston, J. M.: Competing mechanisms for boulder deposition on the southeast Australian coast, Geomorphology, 114, 42-54, 2010.

Tajima, Y., Yasuda, T., Pacheco, B. M., Cruz, E. C., Kawasaki, K., Nobuoka, H., Miyamoto, M., Asano, Y., Arikawa, T., Ortigas, N. M., Aquino, R., Mata, W., Valdez, J., and Briones, F.: Initial report of JSCE-PICE joint survey on the storm surge disaster caused by Typhoon Haiyan, Coast. Eng. J., 56, 1450006, doi:10.1142/S0578563414500065, 2014.

Terry, J., Lau, A. Y. A., and Etienne, S.: Reef-Platform Coral Boulders - Evidence for High-Energy Marine Inundation Events on Tropical Coastlines, Springer, New York, USA, 2013.
Traveglia, C., Baes, A. F., and Tomas, L. M.: Geology of Samar, Bureau of Soils, Department of Agriculture; United Nations Development Programme (UNEP); Food and Agriculture Organization of the United Nations (FAO), Manila, Philippines, 1978.

Verhoef, P. N. W.: Abrasivity of Hawkesbury Sandstone (Sydney, Australia) in relation to rock dredging, Q. J. Eng. Geol. Hydroge., 26, 5-17, 1993.

Weiss, R.: The mystery of boulders moved by tsunamis and storms, Mar. Geol., 295-298, 28-33, 2012.

Weiss, R. and Bourgeois, J.: Understanding Sediments - Reducing Tsunami Risk, Science, 336, 1117-1118, 2012.

Williams, D. M. and Hall, A. M.: Cliff-top megaclast deposits of Ireland, a record of extreme waves in the North Atlantic - storms or tsunamis?, Mar. Geol., 206, 101-117, 2004. 